\title{
Variability and Trends of Rainfall Events in the Brahmaputra Valley of Assam, India
}

\author{
Bikash Jyoti Gharphalia $^{1 *}$, Rajib Lochan Deka ${ }^{1}$, Athar Nishat Islam ${ }^{1}$, \\ Pranjal Dutta ${ }^{1}$ and Kuldip Medhi ${ }^{2}$
}
${ }^{1}$ Department of Agrometeorology, Assam Agricultural University, Jorhat-785013, India
${ }^{2}$ Regional Agricultural Research Station, Gossaigaon, AAU, India

*Corresponding author

\begin{tabular}{|l|}
\hline K e y w o r d s \\
$\begin{array}{l}\text { Rainfall, Trend analysis, } \\
\text { Mann-Kendall rank } \\
\text { statistics, Theil-Sen's } \\
\text { slope method }\end{array}$ \\
\hline Article Info \\
\hline $\begin{array}{l}\text { Accepted: } \\
15 \text { October } 2018 \\
\text { Available Online: } \\
10 \text { November } 2018\end{array}$ \\
\hline
\end{tabular}

\section{A B S T R A C T}

The present study intended to determine potential trends in monthly, seasonal and annual rainfall in the Brahmaputra valley of Assam during 1986-2015, based on observed daily rainfall data from 10 locations. The magnitude of the trends was estimated using TheilSen's slope method, while statistical significance of the trends was tested using MannKendall rank statistics. Analysis revealed that mean annual rainfall varied from $1653.5 \mathrm{~mm}$ in Golaghat to $3676.9 \mathrm{~mm}$ in Gossaigaon, with variability in order of 13-32 per cent at different locations. Annual rainfall was found to decrease in all the 10 stations, with a significant decrease in Golaghat, Dhubri, Kamrup and Tezpur. On seasonal basis, premonsoon rainfall indicated increasing trends at Jorhat, Golaghat, Lilabari, Mohanbari, Beki and Tezpur during the study period. Conversely, rainfall during the monsoon season exhibited significant decreasing trends at Beki, Dhubri, Shillongoni and Tezpur, due to the corresponding significant decrease in July and September rainfall in the locations. Similar decreasing rainfall trends were also observed during post-monsoon season in all the stations. During winter, due to significant decrease in February rainfall, all the stations showed decreasing rainfall trends, with statistically significant values for Golaghat, Lilabari, Mohanbari, Kamrup, Shillongoni and Tezpur, as per Mann-Kendall rank statistics.

\section{Introduction}

Investigating historical changes in the climatic system is recognized as one of the basic necessities of climate change research. The aspect of climate, which most interests the layman and the scientists, is predominantly uncertain, regarding its possible trends (Barry and Chorley, 1987). Climate change studies mostly rely on detecting significant trends in the records of hydro-meteorological variables viz. relative humidity, rainfall and air temperature (IPCC, 2014). In this context, rainfall is of prime interest, owing to its manifestation as a deficient resource or a catastrophic agent. It plays a crucial role as its variations in seasonal and monthly values, coupled with changes in extreme events, can impact on water resources, on natural environments, as well as on human health and safety (Oguntunde et al., 2006, IPCC, 2007). However, there is a large variation in the 
amount of rainfall received at different locations (Attri and Tyagi, 2010). These changes in rainfall pattern exert a significant impact on human's socio-economic activities. Thus, a detailed study regarding the amount, variability and changes in rainfall, along with a complete and accurate description at different spatial and temporal scales has got special attention worldwide in recent years (Markham, 1996). However, reliable weather records have only been kept during the last hundred years or so, and therefore, it is only the recent climatic fluctuations, which can be investigated adequately (IPCC, 1996). At present, the spatial and temporal characteristics of changes in rainfall amounts and concentration have become principal research objects for climate change (Huang et al., 2013). Many researchers have conducted extensive studies on rainfall analysis on seasonal as well as annual scales (Hulme et al., 1998; Parthasarathy et al., 1993; Alexander et al., 2006; Guhathakurta and Rajeevan, 2008; Choudhury et al., 2012; Jain et al., 2013; Patle and Libang, 2014; Asikoglu and Ciftlik, 2015).

For the Indian region, the earliest study was made by Walker (1910), which indicated no significant trend in rainfall in the monsoon season during the second half of the $19^{\text {th }}$ century. Thereafter, studies have been limited to trends and periodicities over specific regions of India by using different data period (Naidu et al., 1999). There are several studies in India on the variability of rainfall and its long term trends (Parthasarathy and Dhar, 1975; Mooley and Parthasarathy, 1984; Sarkar and Thapliyal, 1988; Thapliyal and Kulshresthra, 1991; Guhathakurta and Rajeevan, 2008; Krishnakumar et al., 2009; Kumar et al., 2010; Jain and Kumar, 2012; Bhatla and Tripathi, 2014; Das et al., 2015; Deka et al., 2016; Kothawale and Rajeevan, 2017; Sharma and Singh, 2017). Similarly, there are several studies which focused mainly on the intensity and trends of extreme rainfall events over India, Rakhecha and Soman (1994), Sen Roy and Balling (2004), Joshi and Rajeevan (2006), Rajeevan et al., (2008), Guhathakurta et al., (2010), Gill et al., (2013), Satyanarayana and Kar (2016) and Talchabhadel et al., (2018), to name a few. However, there are only a few studies available on the rainfall variability and trends over northeast India (Das and Goswami, 2003; Das et al., 2011; Deka et al., 2013; Jain et al., 2013; Das et al., 2015; Deka et al., 2016). Since rainfall is having high spatial variability, study of long-term trends of rainfall in smaller spatial scale on daily, weekly, monthly and seasonal time scale is found to be more relevant. For the Brahmaputra valley, where flood is a regular feature, especially during the rainy season, analysis of rainfall trends for the region is of even greater significance.

\section{Climatic characteristics of the study area}

The Brahmaputra valley of Assam is a part of NE India which, in turn, is an integral part of the sub-tropical South-East Asia (Barthakur, 2004). It extends from $26^{\circ} 30^{\prime} \mathrm{N}$ latitude and $92^{\circ} 45^{\prime} \mathrm{E}$ longitude, covering an area of 56,194 $\mathrm{km}^{2}$ (DES, 2016). Being a part of the subtropical belt, the climate of the Brahmaputra valley is akin to the South-East Asiatic monsoon climate (Barthakur, 2004). Climate of the valley is characterized by hot summers and mild to moderately cool winters. The mean annual rainfall of the Brahmaputra valley is $2293 \mathrm{~mm}$ with large spatial variations (Deka et al., 2013), which is generally influenced by orography of the region (Pant et al., 1970; Goswami et al., 2010). The southwest monsoon is responsible for causing the bulk of rainfall, which is about 65 per cent of the annual rainfall over the valley, followed by pre-monsoon rainfall $(25 \%)$, post-monsoon rainfall $(7-8 \%)$ and winter rainfall (2-3\%) (Deka et al., 2013). Variability of annual rainfall over the valley is low, in the order of 
10-18 per cent (Deka et al., 2016). Before the onset of monsoon, there is substantial thunderstorm activity over the region during April and May, as moisture thrusts into the region from the neighbouring Bay of Bengal (Dhar and Nandargi, 2000). Heavy rainfall mostly occurred when the eastern end of the monsoon trough shifts northwards to the valley, or during the periods when 'Break' monsoon situations set in over the country with a northward shift of the monsoon trough to the foot of the Himalayas. These two particular meteorological situations are responsible for causing heavy rainfall on about $65 \%$ of the occasions (Dhar and Changrani, 1966; Dhar and Nandargi, 2003). Cyclonic circulations progress through the OrissaBengal Coast and move in a northwesterly or northerly direction, or re-curve in a northerly or northeasterly direction, thus causing heavy rainfall over the Brahmaputra valley (Ramaswamy and Rao, 1979; Rajeevan et al., 2012).

With 23 per cent of the net cultivated area (28.27 lakh hectares) being flood or drought prone, Brahmaputra valley represents one of the most intense hazard-prone regions in India (Das et al., 2015, DES, 2016). Therefore, the present investigation is carried out, using 10 stations, having quality rainfall data and representing the distinctive features of the river basin, with an objective to strengthen a vivid idea on the recent trend of rainfall in the Brahmaputra valley of Assam.

\section{Materials and Methods}

\section{Data}

Climate change studies require a long period of data in order to identify long- term trends (WMO, 1996). The daily rainfall data cover the period 1986-2015 (30 years) and were recorded at 10 climatological weather stations, representing the Brahmaputra valley of Assam
(Table 1 and Fig. 1). Data for the 10 stations were collected from the Department of Agrometeorology, Assam Agricultural University, Jorhat, India Meteorological Department (IMD), Pune and Regional Meteorological Centre (RMC), Guwahati. From the daily rainfall data, monthly, seasonal and annual rainfall series were calculated for each station. For seasonal analysis, each year has been divided in to four seasons, viz. winter (December-February), pre-monsoon (MarchMay), monsoon (June-September) and postmonsoon (October-November) (Deka and Nath, 2000).

\section{Trend analysis}

\section{Sen's slope}

The magnitude of trend in hydrometeorological time series can be determined using Sen's slope method (Yue et al., 2002). Since the Sen's slope is insensitive to outliers or missing data, it is more rigorous than the usual regression slopes, and thus provides us a realistic measure of the trends in the data series. The approach involves computing slopes for all the pairs of ordinal time points using the median of these slopes as an estimate of the overall slope (Sen, 1968).

The slope estimates $\mathrm{Q}_{i}$ of $\mathrm{N}$ pairs of data are calculated by

$\bar{x}=\frac{\sum_{i=1}^{n} x_{i}}{n}$

For $\mathrm{i}=1,2, \ldots \ldots ., \mathrm{N}$

Where $x_{j}$ and $x_{k}$ are data values at times $j$ and $k$ $(j>k)$ respectively. The median of these $N$ values of $Q_{i}$ is Sen's estimator of slope. If there is only one datum in each time period, then $\mathrm{N}=\mathrm{n}(\mathrm{n}-1) / 2$, where $\mathrm{n}$ corresponds to the number of time periods. The $\mathrm{N}$ values of 
slopes are ranked from the smallest to largest and if $\mathrm{N}$ is odd, Sen's estimator of slope is calculated as

$\mathrm{Q}_{\text {median }}=\mathrm{Q}(\mathrm{N}+1) / 2$

If $\mathrm{N}$ is even, then Sen's estimator becomes $\mathrm{Q}_{\text {median }}=\left[\mathrm{Q}_{\mathrm{N} / 2}+\mathrm{Q}_{(\mathrm{N}+2) / 2}\right] / 2$

A positive value of $Q$ indicates an upward (increasing) trend and a negative value indicates a downward (decreasing) trend in the time series.

\section{Mann-Kendall rank test}

Mann-Kendall rank test (Mann, 1945 and Kendall, 1975) was used to statistically assess the presence of significant trend in the series of rainfall data (Partal and Kahya, 2006), streamflow data (Liu and Zheng, 2004) and water quality data (Donohue et al., 2001). It is a distribution free method, more resistant to outliers, can deal with missing data unlike the parametric method (Wilcox, 1998) and mainly focuses on pair-wise slopes (Alexander et al., 2006).

The MK test statistic (S) is given by

$$
S=\sum_{k=1}^{n-1} \sum_{j=k+1}^{n} \operatorname{sgn}\left(x_{j}-x_{k}\right)
$$

Where $\mathrm{n}$ is the number of data, $\mathrm{x}$ is the data point at times $\mathrm{j}$ and $\mathrm{k}(\mathrm{k}>\mathrm{j})$ and the sign function is given as

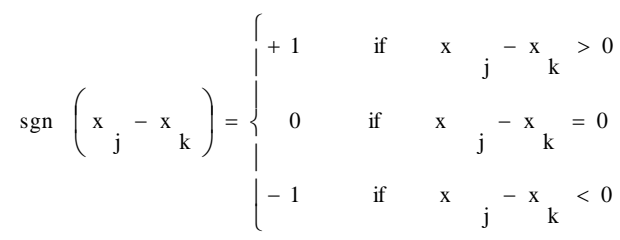

The S statistic, in cases where the sample size $\mathrm{n}$ is larger than 10, is assumed to be asymptotically normal, with $\mathrm{E}(\mathrm{S})=0$ and the variance of $\mathrm{S}$ is computed by

$\operatorname{Var}(\mathrm{S})=\frac{1}{18}\left[\mathrm{n}(\mathrm{n}-1)(2 \mathrm{n}+5)-\sum_{\mathrm{t}} \mathrm{t}(\mathrm{t}-1)(2 \mathrm{t}+5)\right]$

Where $t$ refers to the extent of any given tie and $\Sigma \mathrm{t}$ states the summation over all ties. The standard normal deviate $\mathrm{Z}$ is computed by

$Z=\left\{\begin{array}{ccc}\frac{\mathrm{S}-1}{\sqrt{\operatorname{Var}(S)}} & \text { if } \quad \mathrm{S}>0 \\ 0 & \text { if } \quad \mathrm{S}=0 \\ \frac{\mathrm{S}+1}{\sqrt{\operatorname{Var}(\mathrm{S})}} & \text { if } \quad \mathrm{S}<0\end{array}\right.$

The presence of statistically significant trend is evaluated using the $\mathrm{Z}$ value. In a two-sided test for trend, the null hypothesis $\mathrm{H}_{0}$ should be accepted if $[\mathrm{Z}]>\mathrm{Z}_{\alpha / 2}$, at the level of significance. In this analysis, the null hypothesis was tested at both 90 and 95 per cent confidence level.

\section{Results and Discussion}

\section{Rainfall statistics in the Brahmaputra valley}

Important statistical characteristics (Mean (M), Standard Deviation (SD) and Coefficient of Variation (CV) of monthly and seasonal rainfall series of 30 subdivisions, 5 homogeneous regions and all-India for the period 1901-2013 have been computed. The mean annual rainfall in the Brahmaputra valley varied from $1653.5 \mathrm{~mm}$ in Golaghat to $3676.9 \mathrm{~mm}$ in Gossaigaon, with coefficient of variation $(\mathrm{CV})$ ranging between 13 to 32 per cent at different locations. Maximum amount of rainfall was received during monsoon, followed by pre-monsoon, post-monsoon and winter season at all the selected locations (Table 2). Rainfall during the monsoon season ranged from $1045.4 \mathrm{~mm}$ in Golaghat to 2784.0 
$\mathrm{mm}$ in Gossaigaon. Among all the seasons, $\mathrm{CV}$ was found to be highest in winter season, ranging from 46 per cent in Mohanbari to 94 per cent in Gossaigaon.

\section{Trend analysis}

\section{Monthly rainfall trends}

The trend analysis of monthly rainfall for 10 locations of the Brahmaputra valley during the period 1986-2015 revealed that rainfall is decreasing significantly during the month of February at Golaghat $\left(8.8 \mathrm{~mm} \mathrm{decade}{ }^{-1}\right)$, Lilabari (14.4 mm decade ${ }^{-1}$ ), Mohanbari (16.1 mm decade $\left.{ }^{-1}\right)$, Kamrup (5.3 mm decade $\left.{ }^{-1}\right)$, Shillongoni (9.3 $\mathrm{mm}$ decade $^{-1}$ ) and Tezpur (7.7 $\mathrm{mm} \mathrm{decade}^{-1}$ ) (Table 3).

Similar significant decreasing trends were also observed at Mohanbari (38.4 mm decade ${ }^{-1}$ ), Dhubri (235.5 mm decade ${ }^{-1}$ ), Kamrup (42.4 mm decade ${ }^{-1}$ ), and Tezpur (31.8 $\mathrm{mm} \mathrm{decade}^{-1}$ ) during the month of July, at Mohanbari (66.1 $\mathrm{mm}$ decade $\left.^{-1}\right)$ and Dhubri (110.2 $\mathrm{mm}$ decade $\left.^{-1}\right)$ during September, at Mohanbari $\left(20.3 \mathrm{~mm} \mathrm{decade}^{-1}\right)$, Beki (33.8 $\mathrm{mm} \mathrm{decade}^{-1}$ ) and Tezpur $\left(23.5 \mathrm{~mm}\right.$ decade $\left.^{-1}\right)$ during October, and at Jorhat $\left(4.5 \mathrm{~mm} \mathrm{decade}^{-1}\right)$ and Golaghat $\left(5.0 \mathrm{~mm} \mathrm{decade}^{-1}\right)$ during the month of November (Table 3). On the contrary, positive trends were also observed at different locations, mostly during the months of April and May. However, these values were statistically non-significant.

\section{Seasonal rainfall trends}

Rainfall during pre-monsoon season indicated increasing trends at Jorhat, Golaghat, Lilabari, Mohanbari, Beki and Tezpur (Table 3). However, during monsoon season, all the stations, except Jorhat, showed decreasing trend of rainfall, with statistically significant values for Beki (115.7 mm decade $\left.{ }^{-1}\right)$, Dhubri (570.6 mm decade ${ }^{-1}$ ), Shillongoni (129.3 mm decade $\left.^{-1}\right)$ and Tezpur $\left(92.2 \mathrm{~mm} \mathrm{decade}{ }^{-1}\right)$
(Table 3). This decrease was mainly attributed to the significant decreasing trends in July and September rainfall in these locations. During the post-monsoon season, rainfall exhibited decreasing trends at all locations, with significant values for Jorhat $(23.7 \mathrm{~mm}$ decade $\left.^{-1}\right)$, Beki (32.9 mm decade $\left.{ }^{-1}\right)$, and Dhubri (40.9 mm decade $\mathrm{mm}^{-1}$ ) (Table 3).

Similar decreasing trends were also exhibited by winter rainfall in all the stations, with significant values for Lilabari $(30.8 \mathrm{~mm}$ decade $\left.^{-1}\right)$, Mohanbari (21.5 mm decade ${ }^{-1}$ ) and Shillongoni (14.4 mm decade ${ }^{-1}$ ) (Table 3). This decrease was mainly attributed by the significant decrease of rainfall during the month of February in these stations (Table 3).

\section{Annual rainfall trends}

Table 3 indicated strong decreasing trends of annual rainfall in all the locations. However, the decrease was found to be statistically significant at Golaghat (105.1 mm decade $\left.{ }^{-1}\right)$, Dhubri (637.5 mm decade ${ }^{-1}$ ), Kamrup (100.0 $\mathrm{mm}$ decade $\left.^{-1}\right)$ and Tezpur (122.2 $\mathrm{mm}$ decade $^{-1}$ ) (Table 3).

This was mainly corresponded by the significant decrease of monsoon and postmonsoon rainfall at Dhubri and Kamrup.

From the above study, a decrease in the annual as well as seasonal rainfall was observed in the selected stations of the Brahmaputra valley during the period of study (1986-2015). Mooley et al., (1985) studied the inter-annual variability of all-India summer monsoon rainfall and its association with southern oscillation and sea-surface temperature (SST) for the period of 1871-1978. They reported a significant weakening of the Southern Oscillation and relaxation of the meridional temperature gradient over the Indian Ocean. These were the major factors which inhibited summer monsoon rainfall activity over India. 


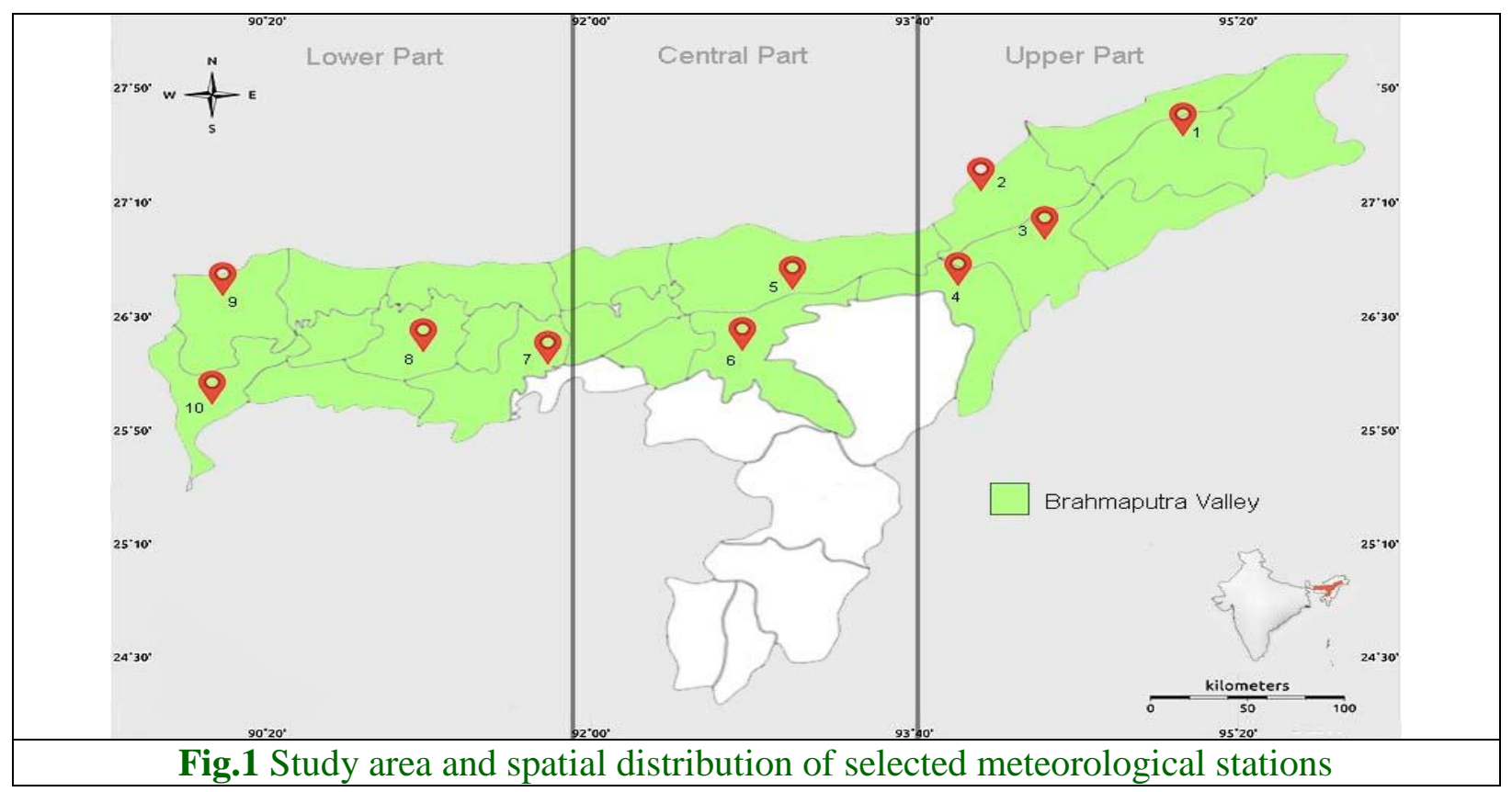

Table.1 List of stations considered for the study

\begin{tabular}{|c|l|c|c|l|c|}
\hline Sl no & Station & Location & Sl no & Station & Location \\
\hline $\mathbf{1}$ & Mohanbari & Upper & 6 & Shillongoni & Central \\
\hline $\mathbf{2}$ & Lilabari & Upper & 7 & Kamrup & Lower \\
\hline $\mathbf{3}$ & Jorhat & Upper & 8 & Beki Rly Bridge & Lower \\
\hline $\mathbf{4}$ & Golaghat & Upper & 9 & Gossaigaon & Lower \\
\hline $\mathbf{5}$ & Tezpur & Central & 10 & Dhubri & Lower \\
\hline
\end{tabular}

Table.2 Station-wise basic statistical characteristics of seasonal and annual rainfall during 1986-2015

\begin{tabular}{|c|c|c|c|c|c|c|c|c|c|c|}
\hline \multirow[t]{2}{*}{ Stations } & \multicolumn{2}{|c|}{$\begin{array}{l}\text { Pre-monsoon } \\
\text { (MAM) }\end{array}$} & \multicolumn{2}{|c|}{$\begin{array}{l}\text { Monsoon } \\
\text { (JJAS) }\end{array}$} & \multicolumn{2}{|c|}{$\begin{array}{l}\text { Post-monsoon } \\
\text { (ON) }\end{array}$} & \multicolumn{2}{|c|}{$\begin{array}{l}\text { Winter } \\
\text { (DJF) }\end{array}$} & \multicolumn{2}{|c|}{ Annual } \\
\hline & $\begin{array}{l}\text { Mean } \\
(\mathrm{mm})\end{array}$ & $\begin{array}{l}\text { CV } \\
(\%)\end{array}$ & $\begin{array}{l}\text { Mean } \\
(\mathrm{mm})\end{array}$ & $\begin{array}{l}\text { CV } \\
(\%)\end{array}$ & $\begin{array}{l}\text { Mean } \\
(\mathrm{mm})\end{array}$ & $\begin{array}{l}\mathrm{CV} \\
(\%)\end{array}$ & $\begin{array}{l}\text { Mean } \\
(\mathrm{mm})\end{array}$ & $\begin{array}{l}\mathrm{CV} \\
(\%)\end{array}$ & $\begin{array}{l}\text { Mean } \\
(\mathrm{mm})\end{array}$ & $\begin{array}{l}\mathrm{CV} \\
(\%)\end{array}$ \\
\hline Jorhat & 484.7 & 27 & 1151.4 & 14 & 133.3 & 58 & 63 & 60 & 1832.5 & 14 \\
\hline Golaghat & 420.5 & 25 & 1045.4 & 19 & 134.0 & 62 & 53.5 & 67 & 1653.5 & 14 \\
\hline Lilabari & 674.5 & 32 & 2208.3 & 16 & 178.9 & 60 & 104.4 & 53 & 3166.1 & 13 \\
\hline Mohanbari & 668.1 & 30 & 1684.3 & 17 & 149.0 & 46 & 96.4 & 46 & 2597.8 & 13 \\
\hline Beki & 671.2 & 28 & 1909.7 & 17 & 160.9 & 53 & 41.1 & 89 & 2782.9 & 15 \\
\hline Dhubri & 597.2 & 33 & 1962.8 & 41 & 178.6 & 78 & 29.3 & 82 & 2767.9 & 32 \\
\hline Kamrup & 487.9 & 31 & 1072.6 & 21 & 140.5 & 59 & 36.5 & 80 & 1737.5 & 15 \\
\hline Gossaigaon & 692.3 & 31 & 2784.0 & 27 & 170.2 & 72 & 30.4 & 94 & 3676.9 & 22 \\
\hline Shillongoni & 394.5 & 22 & 1224.5 & 22 & 126.8 & 65 & 38.5 & 90 & 1784.3 & 19 \\
\hline Tezpur & 491.6 & 23 & 1142.6 & 22 & 123.5 & 52 & 41.5 & 89 & 1799.2 & 17 \\
\hline
\end{tabular}




\section{Int.J.Curr.Microbiol.App.Sci (2018) 7(11): 1902-1912}

Table.3 Sen's estimator of slope $\left(\mathrm{mm} \mathrm{decade}^{-1}\right)$ of monthly, seasonal and annual rainfall in the Brahmaputra valley during the period 1986-2015

\begin{tabular}{|c|c|c|c|c|c|c|c|c|c|c|}
\hline $\begin{array}{l}\text { Months/ } \\
\text { Seasons }\end{array}$ & Jorhat & Golaghat & Lilabari & Mohanbari & Beki & Dhubri & Kamrup & Gossaigaon & Shillongoni & Tezpur \\
\hline January & -2.8 & -1.0 & $-6.3 * *$ & -1.0 & -1.8 & -0.1 & -1.3 & 0 & $-5.3 *$ & -2.2 \\
\hline February & -5.1 & $-8.8 *$ & $-14.4 * *$ & $-16.1 * *$ & -6.2 & -4.0 & $-5.3 * *$ & -0.4 & $-9.3 *$ & $-7.7 *$ \\
\hline March & 0.2 & 2.0 & -7.8 & -9.0 & -0.3 & 5.1 & -7.0 & 8.6 & 0.6 & 0 \\
\hline April & 10.6 & 2.5 & 2.7 & 6.7 & 30.0 & -24.6 & -7.4 & -7.5 & 14.4 & 11.0 \\
\hline May & 24.5 & 3.3 & 30.9 & 21.8 & 7.2 & -48.9 & 2.1 & -42.7 & $-26.9 *$ & -0.1 \\
\hline June & 18.0 & -19.6 & 24.8 & 6.8 & -43.3 & -69.8 & 18.5 & 3.7 & $-47.0 * *$ & -13.8 \\
\hline July & -9.7 & -5.9 & -55.7 & $-38.4 *$ & -79.2 & $-235.5 *$ & $-42.4 * *$ & -112.1 & -51.5 & $-31.8 * *$ \\
\hline August & $23.0 * *$ & -10.9 & 25.5 & 7.9 & -6.0 & -83.3 & -21.3 & -41.6 & $-25.8 * *$ & -34.5 \\
\hline September & -27.7 & -23.1 & -40.8 & $-66.1 *$ & -14.0 & $-110.2 *$ & -17.7 & -41.3 & -26.4 & -20.6 \\
\hline October & -14.6 & -23.8 & -27.2 & $-20.3 * *$ & $-33.8 * *$ & -37.4 & -9.7 & -15.4 & -28 & $-23.5 * *$ \\
\hline November & $-4.5 * *$ & $-5.0 * *$ & 1.7 & -0.4 & -0.5 & -1.9 & -1.4 & 0 & -3.1 & -1.6 \\
\hline December & -0.3 & 0 & 0.2 & -1.0 & 0.0 & 0 & 0 & 0 & 0 & 0.01 \\
\hline $\begin{array}{l}\text { Pre } \\
\text { monsoon }\end{array}$ & 24.7 & 4.5 & 24.3 & 24.3 & 34.0 & -45.3 & -4.3 & -52.6 & -19.2 & 16.5 \\
\hline Monsoon & 13.4 & -87.0 & -24.6 & -71.1 & $-115.7 * *$ & $-570.6 *$ & -37.5 & -87.8 & $-129.3 *$ & $-92.2 * *$ \\
\hline $\begin{array}{l}\text { Post } \\
\text { monsoon }\end{array}$ & $23.7 * *$ & -25.4 & -27.6 & -18.0 & $-32.9 * *$ & $-40.9 * *$ & -11.1 & -16.9 & -25.6 & -23.0 \\
\hline Winter & -9.8 & -10.3 & $-30.8 *$ & $-21.5 *$ & -9.8 & -6.2 & -6.7 & -2.0 & $-14.4^{*}$ & -8.5 \\
\hline Annual & -9.8 & $-105.1 *$ & -110.3 & -104.6 & -138.6 & $-637.5 *$ & $-100.0 * *$ & -213.4 & $-212.1 *$ & $-122.2 * *$ \\
\hline
\end{tabular}

* indicates $5 \%$ level and ** indicates $10 \%$ level of significance as per the M-K rank test 
Mooley et al., (1985) also reported that the meridional sea surface temperature (SST) gradient showed a decreasing trend, which ultimately lead to the weakening of the monsoon circulation. Kripalani et al., (2003) reported that the El Niño Southern Oscillation (ENSO) and the Himalayan/Eurasian Snow were two of the external factors which cause extreme events. The warm phase (El Niño) is associated with weakening of the Indian monsoon with overall reduction in rainfall while the cold phase (La Nina) is associated with the strengthening of the Indian monsoon with enhancement of rainfall (Kripalani et al., 2003).

However, during the recent times, it was observed that the relationship of ENSO and Indian monsoon rainfall was weakening, which might be the possible reasons of decreasing frequency of rainfall events in the study area. Sikka (2006) also reported a decrease in the frequency of rain-producing events in the recent decades over the Bay of Bengal. These decreases in monsoon depressions over the Bay of Bengal might play a major role in the decrease in the amount of monsoon rainfall in the Brahmaputra valley during the period of study (1986-2015).

In this study, long term rainfall data of 10 stations over the Brahmaputra valley was analyzed for spatial and temporal trends at monthly, seasonal and annual basis during the period 1986-2015. From the analysis, it was observed that annual rainfall was decreasing for all the locations during the study period. Seasonal analysis showed that pre-monsoon rainfall increased over 6 out of 10 stations.

On the contrary, monsoon, post-monsoon and winter rainfall exhibited decreasing trends over all the stations. These trends and fluctuation of rainfall pattern are not anticipated to create an alarming situation in the study area. However, the amplification of these trends will very likely aggravate the occurrence of frequent and extreme climate events, thus provoking a major threat to agriculture and allied sectors in the near future.

\section{Acknowledgement}

Authors are grateful to the India Meteorological Department (IMD), Pune and Regional Meteorological Centre (RMC), Guwahati, Assam for providing the data used in this study.

\section{References}

Alexander, L. V., Zhang, X., Peterson, T. C., Caesar, J., Gleason, B., Klein Tank, A. M. G. and Tagipour, A. (2006). Global observed changes in daily climate extremes of temperature and precipitation. J. Geophys. Res. 111 (D5).

Asikoglu, O. L. and Ciftlik, D. (2015). Recent rainfall trends in the Aegean region of Turkey. J. Hydrometeor. 16 (4): 18731885.

Attri, S. D. and Tyagi, A. (2010). Climate profile of India: contribution to the Indian network of climate change assessment (National Communication-II), Ministry of Environment and Forests. Met. Monograph No. Enviro Meteorology. 1: 105-110.

Barry, R. G. and Chorley, R. J. (1987). Atmosphere, weather and climate, Methuen and Co. Ltd., London, Great Britain. 274-328.

Barthakur, M. (2004). Weather and Climate. In: The Brahmaputra Basin Water Resources. Singh, V. P., Sharma, N., Shekhar, C. and Ojha, P. (Eds.). (2013). Kluwer Academic Publishers, Dordrecht, The Netherlands. pp. 17-23.

Bhatla, R. and Tripathi, A. (2014). The study of rainfall and temperature variability over Varanasi. Intl. J. Earth Atmos. Sci. 1 (2): 90-94. 
Choudhury, B. U., Das, A., Ngachan, S. V., Slong, A., Bordoloi, L. J. and Chowdhury, P. (2012). Trend analysis of long term weather variables in mid altitude Meghalaya, North-East India. $J$. Agril. Phys. 12 (1): 12-22.

Das, P. J., and Goswami, D. C. (2003). Longterm variability of rainfall over northeast India. Ind. J. Lands. Syst. Ecol. Stud. 26 (1): 1-20.

Das, S., Bhattacharjee, K., Shaw, S. O., Pathak, H. G. and Patowary, B. (2011). Characteristic pattern and recent trend in rainfall over Guwahati. Proceedings of "Water for Cities: responding to the Urban Challenges", Guwahati, May 30, 2011.

Das, S., Tomar, C. S., Saha, D., Shaw, S. O. and Singh, C. (2015). Trends in Rainfall Patterns over North-East India during 1961-2010. Int. J. of Earth and Atmos. Sci. 2 (2): 37-48.

Deka, R. L. and Nath, K. K. (2000). Rainfall analysis for rainfed crop planning in the Upper Brahmaputra Valley Zone of Assam. J. Agrometeorol. 2: 47-53.

Deka, R. L., Mahanta, C., Nath, K. K. and Dutta, M. K. (2016). Spatio-temporal variability of rainfall regime in the Brahmaputra valley of North East India. Theor. Appl. Climatol. 124: 793-806.

Deka, R. L., Mahanta, C., Pathak, H., Nath, K. K. and Das, S. (2013). Trends and fluctuations of rainfall regime in the Brahmaputra and Barak basins of Assam, India. Theor. Appl. Climatol. 114 (1-2): 61-71.

Dhar, O. N. and Changrani, T. G. (1966). A study of meteorological situations associated with major floods in Assam during the monsoon months. Ind. J. Meteorol. Geophys. 17: 111-118.

Dhar, O. N. and Nandargi, S. (2000). A study of floods in the Brahmaputra basin in India. Intl. J. Climatol. 20 (7): 771-781.

Dhar, O. N. and Nandargi, S. (2003). Hydrometeorological aspects of floods in India. Nat. Haz. 28 (1): 1-33.
Directorate of Economics and Statistics. (2016). Department of Agriculture and Cooperation, Government of Assam.

Donohue, R., Davidson, W. A. Peters, N. E., Nelson, S. and Jakowyna, B. (2001).Trends in total phosphorus and total nitrogen concentrations of tributaries to the Swan-Canning Estuary, 1987 to 1998. Hydrol. Proc. 15 (13): 2411-2434.

Gill, K. K., Kukal, S. S., Sandhu, S. S. and Brar, H. (2013). Spatial and temporal variation of extreme rainfall events in central Punjab. Intl. J. Appl. Engin. Res. 8 (15): 1757-1764.

Goswami, B. B., Mukhopadhyay, P., Mahanta, R. and Goswami, B. N. (2010). Multiscale interaction with topography and extreme rainfall events in the northeast Indian region. J. Geophys. Res. 115 (D12114).

Guhathakurta, P. and Rajeevan, M. (2008). Trends in the rainfall pattern over India. Intl. J. Climatol. 28 (11): 1453-1470.

Guhathakurta, P., Menon, P., Mazumdar, A. B. and Sreejith, O. P. (2010). Changes in extreme rainfall events and flood risk in India during the last century. Research Report No: 3/2010, National Climate Centre, India Meteorological Department, Pune.

Huang, J., Sun, S. and Zhang, J. (2013). Detection of trends in precipitation during 1960-2008 in Jiangxi province, southeast China. Theor. Appl. Climatol. 114 (1-2): 237-251.

Hulme, M., Osborn, T. J. and Johns, T. C. (1998). Precipitation sensitivity to global warming: Comparison of observations with HadCM2 simulations. Geophys. Res. Lett. 25 (17): 3379-3382.

IPCC. (1996). In Climate Change 1995: The Science of Climate Change, Houghton JT, Meira Filho LG, Callander BA, Harris N, Kattenberg A, Maskell K (eds). Cambridge University Press: Cambridge.

IPCC. (2007). Climate Change 2007: Impacts, Adaptation and Vulnerability. Contribution of Working Group II to the Fourth Assessment Report of the 
Intergovernmental Panel on Climate Change.Cambridge University Press, Cambridge, UK. 976.

IPCC. (2014). Summary for policy makers. In Climate Change 2014: Impacts, Adaptation, and Vulnerability. Part A: Global and Sectoral Aspects. Contribution of Working Group II to the Fifth Assessment Report of the Intergovernmental Panel on Climate Change, Cambridge University Press, Cambridge, United Kingdom and New York, NY, USA. pp. 1-3.

Jain, S. K. and Kumar, V. (2012). Trend analysis of rainfall and temperature data for India. Curr. Sci. 37-49.

Jain, S. K., Kumar, V. and Saharia, M. (2013). Analysis of rainfall and temperature trends in northeast India. Intl. J. Climatol. 33 (4): 968-978.

Joshi, U. R. and Rajeevan, M. (2006). Trends in precipitation extremes, India. Research Report No: 3/2006, National Climate Centre, India Meteorological Department, Pune.

Kendall, M.G. (1975). Rank Correlation Methods (London: Griffin).

Kothawale, D. R. and Rajeevan, M. (2017). Monthly, seasonal and annual rainfall time series for all-India, homogeneous regions and meteorological subdivisions: 1871-2016. Research Report No. RR-138). Chennai: IITM.

Kripalani, R. H., Kulkarni, A., Sabade, S. S. and Khandekar, M. L. (2003). Indian monsoon variability in a global warming scenario. Nat. Haz. 29 (2): 189-206.

Krishnakumar, K. N., Rao, G. P. and Gopakumar, C. S. (2009). Rainfall trends in twentieth century over Kerala, India. Atmos. Environ. 43 (11): 19401944.

Kumar, V., Jain, S. K. and Singh, Y. (2010). Analysis of long-term rainfall trends in India. Hydrol. Sci. J. 55 (4): 484-496.

Liu, C. and Zheng, H. (2004). Changes in components of the hydrological cycle in the Yellow River basin during the second half of the $20^{\text {th }}$ century. Hydrol. Proc. 18 (12): 2337-2345.

Mann, H. B. (1945). Non-Parametric Tests against Trend. Econmetrica. 13: 245-259.

Markham, A. (1996). Potential impacts of climate change on ecosystems: a review of implications for policymakers and conservation biologists. Clim. Res. 6: 179-191.

Mooley, D. A. and Parthasarathy, B. (1984). Fluctuations in all-India summer monsoon rainfall during 1871-1978. Clim. Change. 6 (3): 287-301.

Mooley, D. A., Parthasarathy, B. and Sontakke, N. A. (1985). Relationship between allIndia summer monsoon rainfall and southern oscillation/eastern equatorial Pacific sea surface temperature. Proceedings of the Indian Academy of Sciences-Earth and Planetary Sciences. 94 (3): 199-210.

Naidu, C. V., Rao, B. S., and Rao, D. B. (1999). Climatic trends and periodicities of annual rainfall over India. Meteor. Applic. 6 (4): 395-404.

Oguntunde, P. G., Friesen, J., van de Giesen, N. and Savenije, H. H. (2006). Hydroclimatology of the Volta River Basin in West Africa: trends and variability from 1901 to 2002. Phys. Chem. Earth. 31 (18): 1180-1188.

Pant, P. S., Abbi, S. D. S., Gupta, D. K. and Chandra, H. (1970). A study of major rainstorms of Assam. Ind. J. Meteor.Geophys. 21 (2): 189-196.

Partal, T. and Kahya, E. (2006). Trend analysis in Turkish precipitation data. Hydrol. Proc. 20 (9): 2011-2026.

Parthasarathy, B. and Dhar, O. N. (1975). Trend analysis of annual Indian rainfall. $\mathrm{Hydrol}$. Sci. Bull. 20 (2): 257-260.

Parthasarathy, B., Kumar, K. R. and Munot, A. A. (1993). Homogeneous Indian monsoon rainfall: variability and prediction. Proceedings of the Indian Academy of Sciences. Earth Planet. Sci. 102 (1): 121155.

Patle, G. T. and Libang, A. (2014). Trend analysis of annual and seasonal rainfall to 
climate variability in North-East region of India. J. Appl. Nat. Sci. 6 (2): 480-483.

Rajeevan, M., Bhate, J. and Jaswal, A. K. (2008). Analysis of variability and trends of extreme rainfall events over India using 104 years of gridded daily rainfall data. Geophys. Res. Lett. 35 (18).

Rajeevan, M., Unnikrishnan, C. K., Bhate, J., Niranjan Kumar, K. and Sreekala, P. P. (2012). Northeast monsoon over India: variability and prediction. Meteorol. Appl. 19 (2): 226-236.

Rakhecha, P. R. and Soman, M. K. (1994). Trends in the annual extreme rainfall events of 1 to 3 days duration over India. Theor. Appl. Climatol. 48 (4): 227-237.

Ramaswamy, C. and Rao, V. S. (1979). Very Large Floods in the Brahmaputra River in August 1962, Part I: Synoptic Aspects. Mausam. 30 (1).

Sarkar, R. P. and Thapliyal, V. (1988). Climate change and variability. Mausam. 39: 127138 .

Satyanarayana, G. C. and Kar, S. C. (2016). Medium- range forecasts of extreme rainfall events during the Indian summer monsoon. Meteorol. Appl. 23 (2): 282293.

Sen Roy, S. and Balling, R. C. (2004). Trends in extreme daily precipitation indices in India. Intl. J. Climatol. 24 (4): 457-466.

Sen, P. K. (1968). Estimates of the regression coefficient based on Kendall's tau. J. Am. Stat. Assoc. 63 (324): 1379-1389.

Sharma, S. and Singh, P. K. (2017). Long Term Spatiotemporal Variability in Rainfall
Trends over the State of Jharkhand, India. Climate. 5 (1): 18.

Sikka, D. R. (2006). A study on the monsoon low pressure systems over the Indian region and their relationship with drought and excess monsoon seasonal rainfall. Center for Ocean-Land-Atmosphere Studies, Center for the Application of Research on the Environment. COLA Techn. Rep. 217.

Talchabhadel, R., Karki, R., Thapa, B. R., Maharjan, M. and Parajuli, B. (2018). Spatio- temporal variability of extreme precipitation in Nepal. Intl. J. Climatol. 118.

Thapliyal, V. and Kulshrestha, S. M. (1991). Climate changes and trends over India. Mausam. 42 (4): 333-338.

Walker, S. G. T. (1910). On the meteorological evidence for supposed changes of climate in India. General Government Branch Press.

Wilcox, R. (1998). A Note on the Theil- Sen Regression Estimator When the Regressor Is Random and the Error Term Is Heteroscedastic. Biometric. J. 40 (3): 261-268.

WMO. 1996. Some methods of climatological analysis Technical Note No. 81, WMONo. 199. TP.103, Geneva, Switzerland.

Yue, S., Pilon, P. and Cavadias, G. (2002). Power of the Mann-Kendall and Spearman's rho tests for detecting monotonic trends in hydrological series. J. Hydrol. 259 (1): 254-271.

\section{How to cite this article:}

Bikash Jyoti Gharphalia, Rajib Lochan Deka, Athar Nishat Islam, Pranjal Dutta and Kuldip Medhi. 2018. Variability and Trends of Rainfall Events in the Brahmaputra Valley of Assam, India. Int.J.Curr.Microbiol.App.Sci. 7(11): 1902-1912. doi: https://doi.org/10.20546/ijcmas.2018.711.215 